\title{
INTERDISCIPLINARY APPROACH TO THE STUDY OF NATIONAL CONSCIOUSNESS PHENOMENON
}

\author{
Anna Redkina \\ Dniprodzerzhynsk state technical university (DSTU) \\ E-mail address: annaukr@online.ua
}

\begin{abstract}
Keywords: national consciousness, phenomenon, national psychology, inside system transformation, external factors and actions, national interests and values, national identity.
\end{abstract}

\begin{abstract}
The purpose of the article is to investigate the changes of awareness of Ukrainian society interests, acquisition of a new value system as the generating factors of national identity. Problem field is outlined by understanding of the public crisis reasons. The causal relationship between the quality of social transformations and the general atmosphere in the country, the nature of the mass consciousness of Ukrainian population, in particular awareness level of national unity towards the common interest is analyzed.
\end{abstract}

\section{INTRODUCTION}

At the present stage of Ukraine development scientists are faced with quite a difficult task - to understand the causes of social crisis, such its manifestations as economic and political instability, social insecurity of substantial proportion of the population, impairment of educational level, lack of science development, moral decline. Political scientists and experts identified a number of reasons for these circumstances. Besides, the causal relationship between the quality of social transformations and the general atmosphere in the country, the nature of the mass consciousness of Ukrainian population, in particular their level of national unity awareness concerning the common interest were not analyzed sufficiently. Incomplete learning of population identity crisis, factors hindering the way out of this crisis, the tendency of national consciousness development of the Ukrainian society remain the vulnerable spot of this scientific analysis of specified interdependence. Precisely for this reason the study of key aspects (psychological and others) of the national consciousness development of Ukrainian population in the context of state independence, which can reveal the internal mechanisms and optimal conditions for the formation of a multi-ethnic Ukrainian nation and its awareness of historical perspective arouses considerable scientific interest.

Ukrainian science has accumulated specialized experience of studying this problem both theoretically and empirically. However, a number of issues require further deeper, specific and thorough investigation. Social and humanitarian sciences have mainly focused on the study of public opinion on the most morbid issues - political, ideological and geopolitical orientations of different social and regional groups of population. More detailed approach is required for other issues related to clarification and explanation of the reasons and motives of human behavior in various situations (for example, why in some cases they desperately protest against the actions of the authorities of little important problems and show indifference and passivity, when the fate of the country and, consequently, their fate is at stake), evaluation of various social events, phenomena or political figures, their preference giving to some political and ideological orientations, their own identity, and so on.

The solving of this ethno-political tasks on the Ukrainian example will expand the understanding of the specifics of multi-ethnic societies transition to a new level of home policy, economic and socio-cultural relations. From the practical point of view its decision will allow to realize the planning of internal and foreign policies of the country correctly and adequately to the real state of national consciousness. 


\section{METHODOLOGY}

Thus, the purpose of our study is to investigate the changes of awareness of Ukrainian society interests, acquisition of a new value system as the generating factors of national identity.

To achieve the goal of our study we put the following tasks:

1. Determine the conditions and factors affecting the formation and evolution of the national consciousness of the Ukrainian population in the conditions of state independence.

2. Describe the changes in the consciousness of national interests and values by Ukrainian people.

3. Determine the state and prospects of national consolidation of the Ukrainian population.

4. Consider the current state of the national identity of the Ukrainian population.

The object of the study is the national consciousness of the Ukrainian population in the period of independence.

The subject of the study is the changes in the national consciousness of the Ukrainian population during the years of independence.

Research methods used in this work:

1) method of comparative analysis, which enables:

- to discover the specific features and nature of theoretical approaches to the phenomenon under investigation;

- to investigate the tendency of national consciousness development of the Ukrainian population on the results of population census in Ukraine, as well as sociological and statistical studies;

2) historical method to research the formation genesis of national consciousness and national psychology;

3) system-analysis technique, assuming the most comprehensive and integral interpretation of the research subject, first of all, its functional dynamics;

4) method of structural analysis permitting the studying of the current state of national consciousness of the Ukrainian population in the context of the transformation processes of the Ukrainian society;

5) statistical method suggesting the identification of typical behavior and the relationship between the population and the political situation in Ukraine on the basis of sociological data.

Exactly interdisciplinary principle enables to be based on the developments and achievements of a number of scientific disciplines such as political science, ethnopolitology, sociology, ethnosociology, ethnology, general psychology, ethnopsychology, national psychology, social psychology.

The study takes into account modern theoretical approaches and concepts developed by Ukrainian, Russian and Western scientists. The study of basic scientific research paradigms of Ukrainian national consciousness caused to scientific works of key theoretical areas of social sciences.

The works that theoretically can be divided into four groups is a key base for research of development trends of national consciousness of the Ukrainian population:

1. Monitoring, the results of a public opinion poll.

2. Documents, reflecting the state of legal consciousness and legal culture of Ukrainian society - the Ukrainian Constitution, Laws and Decrees of Verkhovna Rada, Ukraine's Presidential Decrees, Codes and other regulations.

3. Media reports of the events concerning the features of political psychology and political behavior of the Ukrainian population.

4. Secondary sources borrowed from the research of our predecessors concerned the subject declared. 


\section{DISCUSSION AND RESULTS}

Considering the theoretical and methodological interpretation problems of national consciousness phenomenon, the options of its substantive content and structure, we consider the component determination to be particularly important, because its studying is conducted in terms of various humanitarian areas. In this study, we are interested in a component of the national consciousness as a national psychology. It is the synthesis of views on the various humanitarian national consciousness makes it possible to develop and explain the conceptual paradigm of Ukrainian national consciousness research.

Having analyzed the sources, containing the scientific concepts of national consciousness phenomenon origin, we had a chance to find out that there is no general consensus about conception of national consciousness in modern science. Accordingly, the understanding of Ukrainian national consciousness phenomenon is in the same state. The debates around this phenomenon are mainly carried out from the standpoint of modernism (B. Anderson, E. Gellner, E. Hobsbaum) and primordialism (D. Llobera, E. Smit). Each of these theories has both weaknesses and strengths. Reconciliation efforts of these positions do not settle their fundamental differences, but set up the base for new theoretical and empirical research. We believe that as representatives of two tendencies agreed on the main components of national consciousness, the best solution would be an approach that synthesizes both directions.

We have proposed own interpretation of national consciousness definition. National consciousness - is a complex spiritual, socio-psychological phenomenon of rational and irrational origin, which is the main property of the nation and typical of an individual, group or community of people. The main components of the national consciousness are the following: national identity with historical memory, loyalty to the language and culture, devotion to the territorial integrity, patriotism, national psychology.

When considering alternatives of content and structure of the national consciousness, we noted that in modern science there is no general consensus by analogy with the definition of national consciousness notion, relative to the structure of this phenomenon. We should take note of a very interesting point of view on the issue of relations between two such important properties of a person as the presence of the unconscious and conscious components in his/her mind: mental activity in the form of unconscious thinking can influence the formation of the national consciousness and its transmission from generation to generation, as our analysis shows, unconscious mental activity is an important factor for the functioning of human consciousness as a whole. However, we cannot find the established (and proven) fact that the unconscious forms the national consciousness in the present-day literature, with the exception of psychoanalytic works. We consider that the structure of the national consciousness, proposed by I. Kresina is the most meaningful and appropriate. First of all, the researcher focuses on such components of the national consciousness as national identity, national idea, national mentality, national psychological complexes.

Considering the substantive content of national psychology notion we made an attempt to compare it with the concept of national consciousness. It should be noted that the two concepts don't have fixed and commonly accepted content and they are interpreted differently by various authors. There is no uniform categorical and terminological approach to the features defining of psychological attributes of one or another nation. For some researchers above mentioned concepts are synonymous, they are used instead of one another and identify their sense. In our opinion, it is appropriate to distinguish between the above mentioned concepts as independent units. However, the distribution of these concepts does not mean the lack of interaction between them. In addition, the interaction is sufficiently close. We take the view that national consciousness is the basis for the formation of national psychology.

We should note that the peculiarity of the national psychology is one of the important characteristics of a nation, and the national psychology traits vary together with changes in the conditions of nation existence. The growth of national consciousness, its formation occurs especially rapidly in the turning-point periods of people life, an example of which is the current 
state of public consciousness in Ukraine. The processes caused by the restructuring of the social, economic and political life of the country led to the growth of national consciousness. This growth is contradictory, at times morbid, due to the controversial nature of the national consciousness.

An important aspect of the study was factors identification in the formation of national consciousness of Ukrainian citizens in the formation process of Ukraine statehood, as well as the functioning of these factors in society. We considered the functioning of psychological heritage of the Soviet period in the minds of the population of Ukraine as a particularly important factor. Here, we identified and examined the so-called psychological type as a "Soviet Ukrainian" - the type of personality that was shaped as a combination result of typical Ukrainians features and the so-called "Soviet Man" during the Ukrainian Republic membership as a part of the USSR. In our view, just this type of person, "the Soviet Ukrainian" led to the psychological state of Ukrainian population in the break-up of the Soviet Union [1]. This psychological type demonstrates the constantly changing level of national consciousness. Among the unique characteristics of this type there is paternalism, but we see the inclination to liberal values, due to the high level of tolerance. One exciting aspect is analysis of public feeling of the Ukrainian population, after referendum in December 1991. 90.3\% of participants voted for independence then, but the following year, only $41.1 \%$ of respondents considered themselves, first of all, citizens of Ukraine, and $12.7 \%$ identified themselves as citizens of a non-existent Soviet Union [2]. These data enable us to maintain that the historic choice in favor of independence was not made as the realization of aspirations for national liberation and development of new social perspectives of civil society, but as the realization of the desire for wealth and security, by which, though at a minimal level, people were provided in Soviet times.

Transformational changes within the system, taking place in post-communist Ukraine, we call another important factor in the national consciousness of the Ukrainian population The formation of a new social consciousness occurs under the influence of this factor. The components of this factor are the following: fundamental changes in the state and political system, the economic foundations of society, intellectual values and priorities as well as the liberalization of the social environment, private property, competition, the new structure of the economy and markets, social anomie, democratization, post-communist social inequality, etc. The Ukrainian alternative of government reforms consists of transition from denationalization and loss of ethnic consciousness to nation project based on the combination of civil cohesion with polyethnicity. Reforming features in transition period of the country also made some changes in the psychology of ordinary Ukrainians. Analyzing sociological data, we conclude that in the first years of post-socialist development under the influence of a deep economic crisis, falling living standards and quality of life, footless expectations for the rapid growth of wealth, the people of Ukraine had to go through drastic changes in social and political mood towards the mass disappointment (in 1992-2014, for example, the index of anomy demoralization was respectively 13.59 [3] and 12.71 [4] points on 18point scale, the index of social cynicism -8.81 and 9.56 points on 14-point scale [5]), which had a negative impact on national integration.

Factor of external actions became a very influential factor in the formation of Ukrainian national consciousness. The transformations taking place in Ukraine are characterized by the transformation processes which are an integral part of the market globalization processes, information flows and socio-cultural area. The largest external actions are felt from Russia, the EU and the United States in Ukraine.

Social studies data show that the conception of different groups of the Ukrainian population about the optimal ways of their homeland appear incompatible, when answering the questions regarding the hypothetical joining of Ukraine to one or another interstate unions. During the 19972006 the proportion of those who react favorably to the idea of Ukraine joining the Union of Russia and Belarus has increased from $53.6 \%$ to $61.0 \%$ [6], in $2014-36.2 \%$. The share of those who have a positive attitude to the idea of Ukraine's joining to the European Union remains relatively high, although in 2000-2014 it was decreased to some extent - from $56.0 \%$ to $50.9 \%$ [7]. The growth of pluralism and multiculturalism on the one hand, and the homogenization and the totality 
of global markets and models of responses to them, on the other hand, create a contradictory situation for the formation of national consciousness of Ukrainian population.

The changes in the main components of the structure of the national consciousness of Ukrainian population during the period of independence is also considered in the research. Studying the national consciousness of Ukrainian population at the turn of XX and XXI centuries, we found it to be a very important the consideration of Ukrainian national interests, values and their impact on public awareness. We have attempted to carry out the matrix comparison of Ukrainian national interests (the retention and strengthening of statehood, the protection of political and economic sovereignty of the country, strengthening of democracy as a common value and a sign of social and cultural identity) with the state of public moods and preferences.

Opinion polls of the population during the years of independence have shown that traditional interests and value-normative system of a Soviet citizen with its illusions of social equality, simplified or automatically adopted values are slowly drifted towards democratic ones. The full transition from the psychological type of personality "Soviet Ukrainian" to the psychological type of personality "democratic Ukrainian" has not happened yet. The weak public interest in politics, the low level of political activity of Ukrainian citizens, the critical perception of multiparty institutions by a large segment of the population, private property and entrepreneurship should be noted among the key indicators of this transition failing. Geopolitical orientations of Ukrainian citizens are also contradictory, and these orientations do not always coincide with the electoral choice. The dominant values of the Ukrainian population are values of survival. Only a small number of citizens of Ukraine felt lack of basic democratic values, which should be equally correlated with the pursuit of material well-being [8]. The above mentioned situation is complicated by the fact that the dissatisfaction with their own lives, the protest potential, which could become the factor of national solidarity, is used by extremist groups to incite enmity.

When considering the Ukrainian national identity as a bearer of the potential psychological consolidation of Ukrainians, it was made an attempt to clarify the state and prospects of formation cultural and political-ideological trait, common to all regions of Ukraine, which would be an indication of the Ukrainian ethnic nation formation. It should be noted, that the process of national identity formation has not been completed, because the territorial identification is dominated in the minds of Ukrainian population and marked regionalism becomes apparent. Having analyzed a lot of aspects of regional differences of Ukrainian citizens, we came to the conclusion, that during the years of independence, regional differences not only leveled, but even increased. The state of national identity is vague, ambivalent, and at present has a rather doubtful psychological consolidation potential. The level of all-Ukrainian identity is falling in the direction from west to east and south from $70.1 \%$ to $34.2 \%$ [9]. But these differences have not been able to outweigh the factors that are still working on the consolidation of Ukrainian ethnic nation. Despite all the differences between the regions, Ukrainian society has still the ability for integration. At the same time Ukrainian citizens by their social and psychological attitudes (through which you can reveal the existence of certain stereotypes) are characterized as a very heterogeneous contingent concerning the sphere of inter-ethnic relations. Tolerance in Ukraine is displaced towards the growth of integral index of national distance, which is fraught with the growth of ethnic prejudice.

\section{CONCLUSION}

So, summing up the research, we should note that the comprehensive analysis of national consciousness of Ukrainian population requires extension, further understanding and forecasting. The scientific value of the research consists in providing an opportunity to use the results and conclusions in the practice of government and public organizations in deciding issues related to inter-ethnic relations, in the argumentation and development of the state ethnic policy toward different ethnic groups and maintaining inter-ethnic harmony in Ukraine. It is an interdisciplinary study vector gave the greatest opportunity to study the phenomenon of Ukrainian national consciousness comprehensively. 


\section{References}

[1] Redkina G. M., National consciousness of the Ukraine population in the conditions of state independence, Manuscript, The thesis for a degree of Candidate of political sciences in the speciality: 23.00.05, Ethnic Political and Ethnic State Sciences, nstitute of Political and Ethnic Studies after I. F. Kuras National Academy of Sciences of Ukraine, Kyiv, 2008, 222 p.

[2] Outcomes of the national annual monitoring surveys of 1992-2006, in: Ukrainian Society 19922006. Sociological Monitoring, Kyiv, Institute of Sociology of the NAS of Ukraine, 2006, p. 419-569.

[3] V. Vorona, Introduction, in: Ukrainian Society 1992-2006. Sociological Monitoring, Kyiv, Institute of Sociology of the NAS of Ukraine, 2006, p. 3-9.

[4] T. Zahorodniuk, Socio-psychological state of population in the course of cardinal changes in the vector of formation of social order in Ukrainian society, in: Ukrainian Society: Monitoring of social changes, Kyiv, Institute of Sociology of the NAS of Ukraine, 2014, p. 402-409.

[5] Ye. Golovakha, Social cynicism and anomia in Ukrainian society: general dynamics and recent changes, in: Ukrainian Society: Monitoring of social changes, Kyiv, Institute of Sociology of the NAS of Ukraine, 2014, p. 49-56.

[6] Outcomes of the national annual monitoring surveys of 1992-2006, in: Ukrainian Society 19922006, Sociological Monitoring, Kyiv, Institute of Sociology of the NAS of Ukraine, 2006, p. 419-569.

[7] V. Reznik, The grounds of social order in the present-day Ukrainian society: preferences of Ukrainian citizens, in: Ukrainian Society: Monitoring of social changes, Kyiv, Institute of Sociology of the NAS of Ukraine, 2014, p. 24-36.

[8] Ukrainian society 1992-2013, Current state and dynamics of changes. Sociological monitoring, Edit. by V. Vorona, M. Shulga, Kyiv, Institute of Sociology of the NAS of Ukraine, 2013, $566 \mathrm{p}$.

[9] I. Prybytkova, Ukraine in regional-civic and ethnolinguistic dimensions in the epoch of changes, in: Ukrainian Society: Monitoring of social changes, Kyiv, Institute of Sociology of the NAS of Ukraine, 2014, p. 196-210. 